\title{
OBSERVATION OF FEMALE DORM PRIVACY IN ISLAMIC BOARDING SCHOOLS IN WEST JAVA, INDONESIA
}

Received August 5th, 2021 | Accepted November 18th, 2021 | Available online December 15th, 2021

DOI http://dx. doi. org/10.18860/jia.v6i4.13091 |

\section{Rangga Firmansyah}

Interior Design Study Program, Telkom University, Indonesia.

ranggafirmansyah@telkomuniversity.ac.id

\section{Nazlina Shaari}

Faculty of Design and Architecture, Universit Putra Malaysia (UPM), Malaysia.

nazlinashaari@upm.edu

\section{Sumarni Ismail}

Faculty of Design and Architecture, Universiti Putra Malaysia (UPM), Malaysia.

sumarni@upm.edu.my

\section{Nangkula Utaberta}

Faculty of Civil Engineering Built Environment, Universiti Tun Hussein Onn, Malaysia.

nangkula@uthm.edu.my

\section{Ismar MS Usman}

Department of Architecture

Faculty of Engineering and Built Environment,

Universiti Kebangsaan Malaysia

Malaysia

\begin{abstract}
In learning activity processes in Islamic boarding schools, students must study and live in a dormitory. It functions to replace a residential home where the privacy aspect should be taken into consideration. This study aims to observe the privacy aspects closely related to the female students bedrooms, covering six elements examined in five case studies, including the sex-segregated dormitories, the main function of staying, visual privacy on the dimensions $\&$ height of the windows, acoustic privacy, and olfactory privacy in terms of the connection between dormitory rooms. It was found that the privacy aspect in the dormitory room still lacked attention due to the addition of space functions and bathroom facilities in it. Meanwhile, adding personal facilities, such as storage and study areas, could enhance the students' privacy. Especially for the type of student bedroom, it is necessary to provide a place for drying clothes by utilizing the balcony area. Besides that, it is required to pay attention to the type, dimensions \& direction of window openings so that the level of privacy of female students will be more optimal.
\end{abstract}

\section{KEYWORDS:}

Privacy; bedrooms; dormitories; Islamic boarding schools; female

\section{INTRODUCTION}

Pondok Pesantren is known as "communitybased Islamic education institutions that provide religious education. It usually consists of several main buildings, such as mosques, school buildings, and dormitories. The term "student dormitories" or student residence is widely used to refer to the student accommodation facilities ranging from schools to the university level. In Indonesia, it is commonly called a boarding school. However, it is slightly different from the pesantren, the rooms used by students to stay overnight are better known as "Pondok". In the country, Pondok is a place to live made of bamboo, while in Arabic, "funduq" means a large hostel provided for a stopover. If it is linked to the pesantren environment, Pondok means the boarding school for the santri. [1]-[7].

This study observed the privacy in male \& female dormitories in five modern Islamic boarding schools in West Java, Indonesia. Privacy in the study is used based on the importance of this aspect in studying Islamic design principles found in residence. It is relevant to be used in dormitories function as lodging facilities for students. As part of facilities in an
Islamic-based education environment, it is vital to evaluate privacy as one of the requirements for Islamic design principles. In the future, it will be helpful for foundations, architects, and designers in planning Islamic boarding school dormitories. It has the same meaning as the standard of boarding school, which leads to preference $\&$ adaptation aspects [8].

Based on Islamic values, there are several recommendations in the Qur'an, and the Hadith of the Prophet SAW regarding the arrangement and relations between spaces as a form of Islamic architectural concept, also regulating the rights of Muslim privacy [9],[10]. Some of them are;

1) Maintain each other's privacy for each occupant. In the Qur'an, Allah SWT says:

"O you who believe, let the slaves (male and female) that you have, and those who are not yet mature among you, ask permission from you three times (in one day) namely before the morning prayer, when you take off your your (outer) clothes in the middle of the day, and after the evening prayer ..." (Surah an-Nur (24): 58-59). The verse explains social etiquette in the house, where privacy must be strictly 
maintained; in the aspect of the dormitory room, it is necessary to pay attention to the arrangement of furniture for each student.

2) Separate a place or bedroom for children. "Tell your children to pray when they are seven years old and use a beating when they are ten years old and separate their beds" (HR Abu Dawud). One way to apply this hadith is to provide a bed for each student.

3) Maintain the privacy of residents against guests and relatives who are not mahram. The Prophet Muhammad SAW said, "A guest who enters the house of a people, should sit in the place designated by the people, because they are more familiar with the places of their private parts in their homes" (HR at Thabrani). Keeping and covering the genitals is still obligatory if there are people who are not mahrams in the Muslim house, so it is necessary to pay attention to the type \& dimensions of the window openings in the dorm room.

Boarding school planning standards and guidelines differ significantly from public schools for several reasons. Planning for such programs often requires a more powerful program setup that requires a detailed analysis of exercise and extracurricular activities. In addition, the school needs to provide a home element. There are major differences between the facilities of different boarding schools. Moreover, Islamic boarding schools need to provide house elements because the activity lasts for 24 hours.

There are several alternative architectural designs from the application of the concept of privacy inside and outside Muslim residences [11], including: 1) There are clear boundaries between private and public zones in the room along with the arrangement of orientations and relationships between spaces, 2) Several spaces can be placed side by side or adjacent, without having any visual relationship to each other, 3) Flexibility of space utilization, this is by designing multifunctional spaces in one room, 4) Building separation, fulfilling the need for privacy can be realized by separating buildings for male and female purposes, 5) Separation of access in and out.

Numerous studies show the importance of dormitories' design standards that need to be met. Variable and indicators that used are activity, facility, pesantren scope, dormitory building scope, floor scope, bedroom scope, and shared facilities [12]-[15]. The stages in designing a dormitory in a pesantren are identifying the characteristics of the type of pesantren that will be designed, then looking for typologies from several similar pesantren [8].

Privacy in Islamic design principles has been widely investigated, especially in residential homes [16] -[19]. Privacy evaluation in student dormitories showed that each student needed privacy in the room [20]. This analysis discusses the privacy aspects of female dormitories, which are used as residential areas for the students in the Islamic boarding school area.
There are four layers of privacy in residence; i) privacy between neighboring residential buildings, ii) privacy between women \& men, iii) privacy between family members at home, \& iv) privacy of individuals [21]. Concerning the activity pattern in the dormitory, the relevant aspects of privacy for evaluation are; i) separation of male \& female dormitory buildings, ii) the main function of staying, iii) visual privacy (dimensions \& window height position), iv) acoustical privacy in terms of the connection between dormitory rooms, v) olfactory privacy in terms of the connection between dormitory rooms.

Based on the discussion of the literature above, we can conclude that there are five variables for observation in this study case as follows:

1) Sex segregation in dormitory buildings;

2) The main function of staying overnight. These two aspects were generally explored at the beginning of this study;

3) Visual privacy (dimensions \& height of the window) data were obtained through image studies and measurements in the case studies. To achieve this visual privacy, the window's height must be above the level of human's eyes or about $145 \mathrm{~cm}$, so people outside cannot see into the room.

4) Acoustical privacy in terms of the connection between dormitory rooms. The data were obtained through surveys conducted during the case study and image studies using digital applications to create image layout and interviews with students regarding problems.

5) Olfactory privacy in terms of the connection between dormitory rooms. The data were obtained.

6) Through surveys in the case study and image studies using digital applications to create layout images and interviews with students regarding the existing inconvenience.

\section{PROBLEM STATEMENTS}

Islamic boarding schools require students to live in a dormitory with others [22]. Such an environment aims to foster the students being more independent and socialize well with other pesantren members as the first step in socialization with the community.

Research that explicitly takes the study of female student rooms in Islamic boarding schools is still very minimal. Many similar studies are needed to enrich the findings of existing research.

For many santri in their teenage years, living in a dormitory is part of the experience that builds their future personalities. Changes in the dormitory life will be one of the determining factors of their social experience in society. It will also affect their academic achievement and behaviors in a boarding school for 24 hours a day. Thus, decent accommodation is an important priority to support religious education in Islamic boarding schools. The dormitories must fulfill students' needs and necessities, academic changes, 
and social life. Student's and parents' records are among those that need to be considered [8].

\section{METHODOLOGY}

This study used a qualitative research model to interpret the privacy aspect in female dormitory rooms of boarding schools. Qualitative methods seek to understand and interpret the meaning of an event of human behavior interaction in certain situations according to the researcher's own perspective. Research that uses qualitative research aims to understand the object being studied in depth [23], [24]. Using qualitative research methods, study findings are revealed naturally to deduce new opinions and test initial variables taken from previous theories [20],[21]. Since there are many Islamic boarding schools in Indonesia, the selection in this case study was focused on the West Java area, Indonesia, by using a snowball sampling technique. In snowball sampling, the beginning starts with a person or case that meets the research criteria. Then based on the direct or indirect linkages in a network, the next respondent or the next sample unit can be found.

Informants in the qualitative method continue to develop (snowball) purposively until the data collected is considered satisfactory or saturated (redundancy). The data collection tool or research instrument in the qualitative method is the researcher himself. So, the researcher is a key instrument. In collecting data, the researcher must be actively involved in the field himself. Data collection techniques used were: participatory observation, interviews \& documentation [27], [28].

Evaluation \& investigation of privacy aspects in their dormitory buildings were conducted through direct observation on-site and interviews [23], [24]. In this regard, this study is limited to five cases, and, therefore, the research samples consist of five boarding schools in West Java. For the research sampling, the boarding school dormitory buildings were categorized according to the following aspects:

1) a similar type of male and female dormitory building,

2) modern Islamic boarding schools,

3) a full boarding system (overnight stay for students),

4) located in West Java.

Based on the four categories above, five Islamic boarding schools from different regencies in West Java were selected;

1) Case study 1: Al-Zaytun Ma'had Islamic Boarding School, Indramayu.

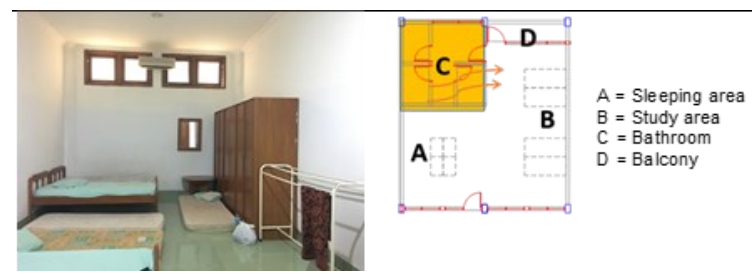

Figure 1. Showing floor plans and furnishing layouts of case study 1's bedroom. (Source: Authors, 2021)
2) Case study 2: Al Kausar Islamic Boarding School, Sukabumi.

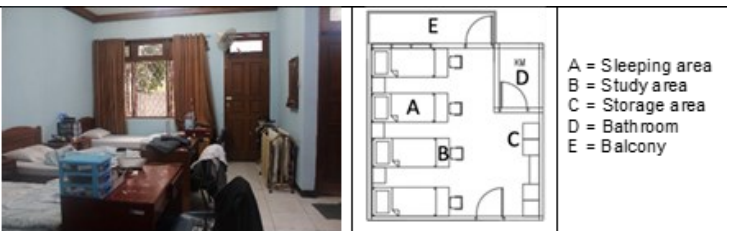

Figure 2. Showing floor plans and furnishing layouts of case study 2's bedroom. (Source: Authors, 2021)

3) Case study 3: Al Ma'soem Islamic Boarding School, Sumedang.

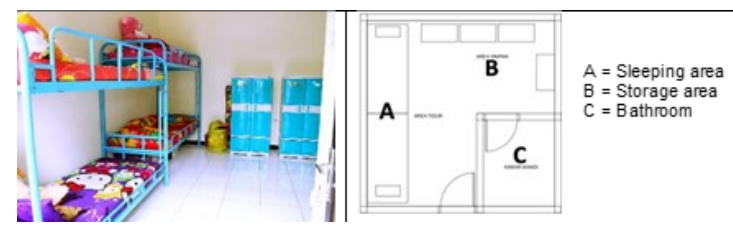

Figure 3. Showing floor plans and furnishing layouts of case study 3 's bedroom. (Source: Authors, 2021)

4) Case study 4: Al-Basyariyah Islamic Boarding School, Bandung.

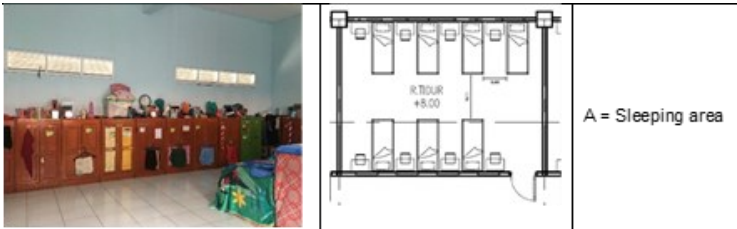

Figure 4. Showing floor plans and furnishing layouts of case study 4's bedroom. (Source: Authors, 2021)

5) Case study 5: Al-Muttaqin Islamic Boarding School, Tasikmalaya.

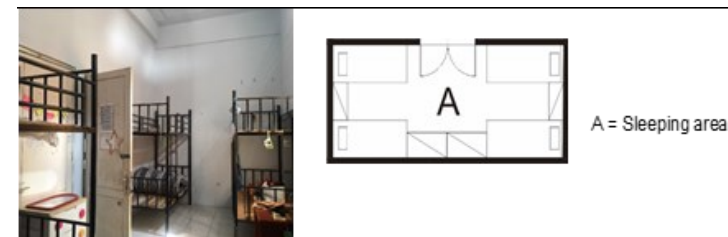

Figure 5. Showing floor plans and furnishing layouts of case study 5 's bedroom. (Source: Authors, 2021)

In the discussion section of the results, according to the previous literature review, the researchers look for the following five instruments; sex segregation in dormitory buildings, the main function of overnight accommodation, visual privacy (window's dimension \& height), acoustical privacy, \& olfactory privacy.

To deepen the findings, in general, in-depth interviews were conducted with representatives of female students and representatives of female teachers to obtain results regarding the privacy of female students in particular. Interviews were conducted naturally \& unstructured to avoid intervention and cause over-sensitivity. 


\section{RESULTS OF ANALYSIS}

According to the qualitative research method used, the analysis was arranged sequentially from case study 1 to case study 5, and data findings were carried out by observing five Islamic boarding schools. The following paragraphs are the description of the research findings arranged in tabulations.

\section{SEX SEGREGATION IN DORMITORY BUILDINGS}

Case study 1. The Ma'had Al-Zaytun Islamic Boarding School Indramayu has a female dormitory building and two separate male dormitory buildings. The dormitory building consists of five stories which accommodate around 7,800 students. The other facilities at the Ma'had Al-Zaytun Islamic Boarding School consist of an administration building, laundry, and a separate dining room.

Case study 2. Al Kausar Islamic Boarding School Sukabumi provides separate buildings for male \& female dormitories and also separate mosques for males and females. The dormitory building is also equipped with a lobby room, supervisor's bedroom, and dormitory administration room.

Case study 3. Al Ma'soem Islamic Boarding School

Sumedang has separate male \& female dormitory building facilities, consisting of three floors which can accommodate around 800 students. The building consists of a lobby area on the ground floor, a supervisor's room, students' rooms, and a bathroom in each room. In this Islamic boarding school area, a building for canteen is separated from the dormitory building.

Case study 4. Al-Basyariyah Islamic Boarding School, Bandung consists of separate male and female dormitory buildings. Its main function is for an overnight stay for the students.

Case study 5. Al-mutaqien Islamic Boarding School, Tasikmalaya. Male and female students stay in the same dormitory building but with different access doors. The building consists of two floors. The right side of the building is for male students, while the left one is for a female student.

\section{THE MAIN FUNCTION OF OVERNIGHT ACCOMMODATION}

Case study 1. At the Ma'had Al-Zaytun Islamic Boarding School, Indramayu, a room is occupied by eight students using bunk beds which is to reduce space clutter. In addition, the area for study is combined in one area so that individual learning privacy for each student is not fulfilled.

Case study 2. Al Kausar Islamic Boarding School, Sukabumi. It has bedroom facilities occupied by four students using four single-level beds, so the students have a private area to rest. Each student has their study area, i.e., a study desk is at the front of the bed.

Case study 3. Al Ma'soem Islamic Boarding School, Sumedang. Four students occupy each room with a single bathroom. There are no private study facilities in the bedroom for each student, and there is also no communal study room in the building.
Case study 4. Al-Basyariyah Islamic Boarding School, Bandung. More than eight people occupy the bedroom without private bed facilities (mattresses are spread directly on the floor). The main function of the dormitory is only to accommodate overnight stay without any other supporting facilities. In addition, there are no footwear storage facilities, so the footwear is scattered on the building terrace.

Case study 5. Al-Mutaqien Islamic Boarding School, Tasikmalaya. Eight students' bedrooms are occupied using four bunk beds, so each student has a private area to rest. However, there are no other supporting facilities, such as study areas and bathrooms in the bedrooms, so that the main function is only intended as a place to rest.

\section{VISUAL PRIVACY (WINDOW'S DIMENSION \& HEIGHT)}

In all case studies (1,2,3 and 4), the window's height in each room of the Dormitory (Ma'had AlZaytun Islamic Boarding School, Al Kausar Islamic Boarding School, Al Ma'soem Islamic Boarding School, Sumedang, and Al-Basyariyah Islamic Boarding School, Bandung) is about $90 \mathrm{~cm}$, covered with a curtain. The window's height is considered as a house standard. Therefore, the students inside the room can access the view outside and vice versa. Given such a situation, there may be discomfort for students inside the room. Meanwhile, in case study 5, the Al-Muttaqin Islamic Boarding School Tasikmalaya has a window's height of about $180 \mathrm{~cm}$. Therefore, students in the room cannot access the view outside, nor can people from outside see what is happening inside the room.

\section{ACOUSTICAL PRIVACY}

In the case of studies 1, 2, 3 (Ma'had Al-Zaytun Islamic Boarding School, Al Kausar Islamic Boarding School, and Al Ma'soem Islamic Boarding School, Sumedang), each room has bathroom facilities. However, it causes the students' discomfort, especially from learning privacy. The bathroom is in the bedroom space, creating acoustic disturbances, such as during washing clothes. Meanwhile, in the case of studies 4 and 5 (Al-Basyariyah Islamic Boarding School, Bandung, and Al-Muttaqin Islamic Boarding School, Tasikmalaya), the dormitories do not provide bathroom facilities in each room, so the main room function is just for rest.

\section{OLFACTORY PRIVACY}

In case of studies 1, 2, 3 (Ma'had Al-Zaytun Islamic Boarding School, Al Kausar Islamic Boarding School, and Al Ma'soem Islamic Boarding School, Sumedang), the dormitory functions as a place to stay for students with bathroom facilities for each bedroom, causing odor disturbances to the bedroom area. In addition, there are other activities such as laundry in the bathroom and clothes drying on the balcony even though the building management provides a centralized laundry service facility.

Meanwhile, in the case of studies 4 and 5 (AlBasyariyah Islamic Boarding School Bandung and Al- 
Muttaqin Islamic Boarding School Tasikmalaya), the rooftop building used for drying clothes is a clothesline area that is separate from the building. Although laundry facilities are available for students, in case study 4, no footwear storage facilities that are available causing olfactory disturbances due to the scattered footwear on the building terrace.

\section{DISCUSSION}

This section only focused on the study findings that indicate problems affecting students' privacy in the bedroom. Variable 1 includes two aspects, namely sex-segregated dormitory and function for overnight stay. Furthermore, for variable 2 consists of three things, namely visual privacy, acoustical privacy, and olfactory privacy.

Table 1. Variable privacy of concern

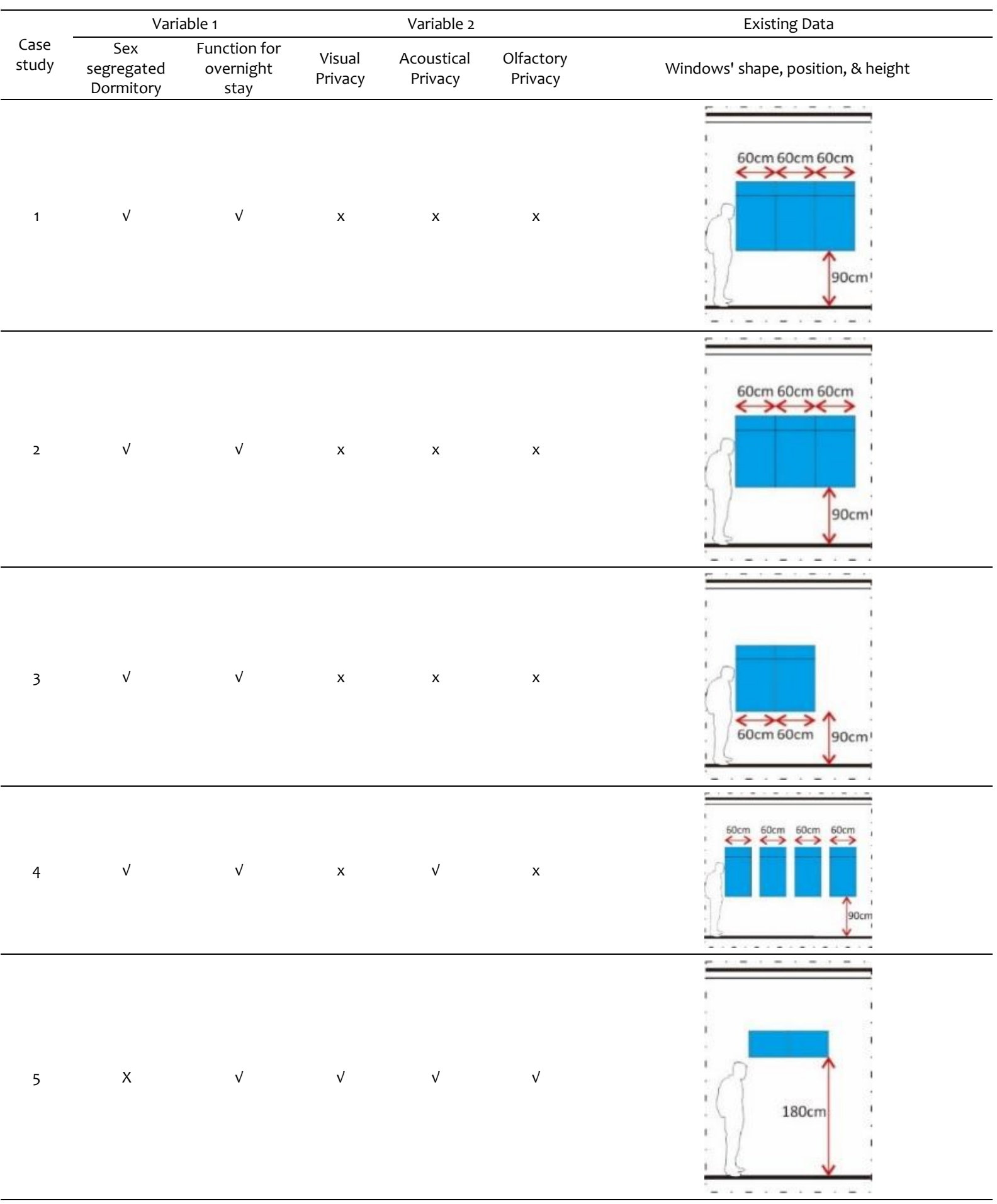


Sex segregation in the dormitory building for male and female students affects the privacy of the students. This aspect affects the student's comfort while doing activities in the building. In five study cases, all boarding schools separate male \& female dormitory buildings, except one study case that implements sex integrated dormitory in one facility by separating floor levels and access. It showed that the segregation between males and females is crucial because it is a mandatory part of Islamic values. During the Prophet's life, women were separated from men both on special occasions and in common public life.

The factor of occupants density in the dormitory affects the privacy aspects of the santri (students), allows them to study more conveniently, and social interactions can be more controlled compared to a higher occupant number, such as in dormitories in many schools [29]-[31]. In the five study cases, the average occupant number of students in the dormitory room was eight students. Only one case applied one room occupied by four students, which showed that the student's privacy in the dormitory room was not ideal due to the higher occupant density.

Centralizing the primary function of boarding school as a residential place enables the students to study with all the supporting facilities for their daily activities. In the five study cases, all Islamic boarding schools implemented the primary function of the building as a residential place. At the same time, bathing, laundry, clothes drying could affect the students' privacy in the dormitory rooms.

Visual privacy aspects can be viewed from the windows' height in the students' rooms. To achieve this type of privacy, the position of the window's height is above the height of the human eye or about $145 \mathrm{~cm}$ so that it is not visible to outsiders. In the five study cases, four cases had a window's height of about $90 \mathrm{~cm}$, while only one case had a height of about $180 \mathrm{~cm}$, and all of them used a curtain as a window's covering. It showed that the Islamic boarding schools lack attention to the student's visual privacy in the room.

Meanwhile, the acoustic privacy aspect influenced students' activities, especially during rest and study. Among the noise, the disturbance is the sound from the private bathroom. In the five study cases, three Islamic boarding schools had bathrooms in the bedrooms, and the other Islamic boarding schools separated the bathroom from the bedroom using a communal model.

Furthermore, olfactory privacy is an important aspect that affects students' comfort in the bedroom. Odor coming from the bathroom, food, dirty clothes, shoes, and socks can annoy the students' privacy. In the five study cases, three Islamic boarding schools had private bathrooms, while the other two cases used a communal bathroom separated from the bedroom.

Regarding these new findings that affected the students' privacy, the dormitory provides additional facilities, such as private beds, storage, and learning activities for each student. The data were obtained by observation in each bedroom in five study cases.

Table 2. Additional private facilities in each case study

\begin{tabular}{|c|c|c|c|c|c|}
\hline \multirow{2}{*}{ Private Facilities } & \multicolumn{5}{|c|}{ Case study } \\
\hline & 1 & 2 & 3 & 4 & 5 \\
\hline Bedroom facilities & 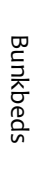 & 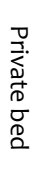 & 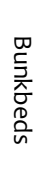 & 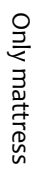 & 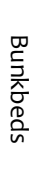 \\
\hline Storage & V & $\mathrm{V}$ & $\sqrt{ }$ & $\mathrm{V}$ & $\checkmark$ \\
\hline Study area & $\mathrm{X}$ & $\mathrm{V}$ & $x$ & $\checkmark$ & $\mathrm{x}$ \\
\hline
\end{tabular}

The results obtained were related to rest facilities as the primary function for the students' overnight stay. In the five study cases, three Islamic boarding schools used bunkbeds (two-tiered beds), one Islamic boarding school used the private bedstead, and the other used only mattresses. It showed that not all Islamic boarding schools have paid attention to the students' comfort in rest activities. Safety is a factor that needs consideration regarding using a bunkbed (two-tiered bed) when climbing and descending the bed stairs. At the same time, a case study that only provides a mattress tends to lack thermal comfort because it is directly spread on the floor.

In the five study cases, all boarding schools had facilitated private storage for the santri. It showed that storage facilities are important and indispensable because they can affect the dormitory bedrooms cleanliness, spacious comfort, and tidiness. Besides, this factor could keep the student's items safer.

Learning is the main activity in the dormitory room apart from resting. In the five study cases, two Islamic boarding schools had private study areas, one Islamic boarding school had a communal study area, and two had no study areas. It showed that some Islamic boarding schools only function rooms to rest, even though learning activities are common for students.

The facilities provided included five things, including sleeping, storing, studying, and adding balcony areas. The typology of bedroom size was found in five types: very small, small, medium, large, and extra-large. The number of occupants found were (a) 4-10 people; (b) 11-20 persons; (c) 21-30 persons; (d) 31-40 persons; and (e) 40-50 persons. The type of occupant was based on level of the school, grade, major, interest and mixture. The aspect of bedroom area per person in the bedroom was found the minimum type and below the minimum type [32]. The following is an illustration of the ideal type of bedroom based on a comparison of five research case studies and modifications considering the standard literature. 


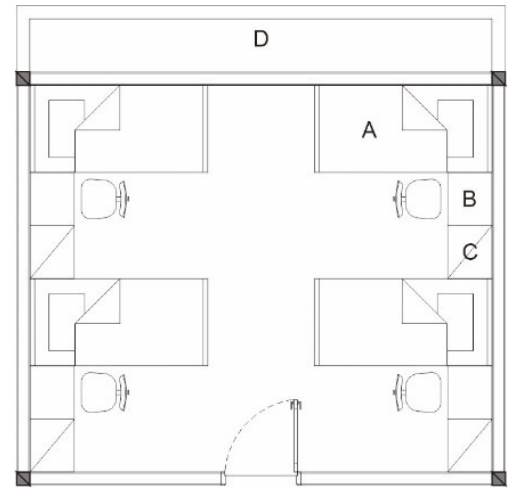

Layout Plan A

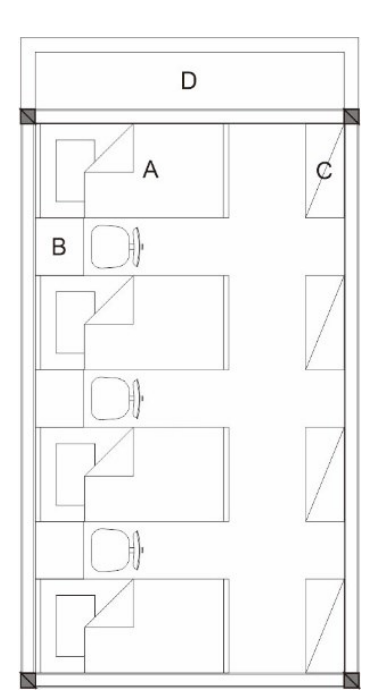

A: Sleeping

Area

B: Study

Area

C: Storage

D: Balcony

Layout Plan B

Figure 6. Showing 2 alternative modifications to the layout of the furnishing $\&$ balcony area in the dormitory bedroom

Specifically for the female student's room, the balcony can function as a drying area. Based on the results of in-depth interviews with female students, although laundry facilities had been provided from the Dormitory, female students preferred to wash themselves for certain clothes. Based on the observations, there were still drying areas for female students in the rooms and bathrooms, which caused odor and visual disturbances. Meanwhile, to maintain the privacy of female students in the bedroom, it is necessary to pay attention to the dimensions, type of windows, and orientation of window openings so that they do not directly face the male student dormitory building.

\section{CONCLUSIONS}

Santri's room privacy in the Islamic boarding school still needs attention and improvements in the future. Based on the study results and discussions on five case studies of Islamic boarding schools in West Java, it can be concluded that the auxiliary room function causes privacy problems in dormitory bedrooms other than as a place to stay, such as a bathroom that causes noise and olfactory disturbances, windows positions, and dimensions that can reduce visual privacy to the occupants. Meanwhile, with the addition of a study area, applying a communal type bathroom and a private storage area in the dormitory bedrooms can provide privacy for students. In particular, for the type of bedroom for female students, it is necessary to pay attention to the need for drying by utilizing the balcony area and pay attention to the type and dimensions of window openings, so that the level of privacy for female students will be more optimal.

\section{REFERENCES}

[1] O. Herman, "Jurnal Al-Ta'dib Vol. 6 No. 2 Juli Desember SEJARAH PESANTREN DI INDONESIA," vol. 6, no. 2, pp. 145-158, 2013.

[2] A. Tolib, "Pendidikan Di Pondok Pesantren Modern Terpadu," Risalah, vol. 1, no. 1, pp. 6066, 2015.

[3] G. Abdul and N. Zakaria, "Pondok Pesantren[? Changes and Its Future Pondok Pesantrent?: Changes and Its Future," no. January, 2016.

[4] T. Hidayat, A. S. Rizal, and F. Fahrudin, "Peran Pondok Pesantren Sebagai Lembaga Pendidikan Islam di Indonesia," Ta'dib J. Pendidik. Islam, vol. 7, no. 2, pp. 1-10, 2018, doi: 10.29313/tjpi.v7i2.4117.

[5] R. Lukens-Bull, "MADRASA BY ANY OTHER NAME: Pondok, Pesantren, and Islamic Schools in Indonesia and Larger Southeast Asian Region," J. Indones. Islam, vol. 4, no. 1, p. 1, 2014, doi: 10.15642/jiis.2010.4.1.1-21.

[6] Y. Purwanto and C. N. Siregar, "Pesantren dalam Kebijakan Pendidikan Indonesia Pendahuluan Islam yang indigenous ' asli ' di Indonesia . Pesantren termasuk masuk dalam UU No 20 Tahun 2003 tentang Sistem Pendidikan penduduk usia 15 tahun ke atas masih besar . Angka Partisipasi," J. Lekt. Keagamaan, vol. Vol. 15, N, no. Pesantren dalam Kebijakan Pendidikan Nasional, pp. 233-272, 2017.

[7] P. D. H. H. P. D. M. A, Sejarah Pertumbuhan \& Pembaruan Pendidikan Islam di Indonesia. Kencana Prenada Media Group, 2018.

[8] M. A. Yusuf, A. Hayati, and M. Faqih, "Design Parameters of Pesantren's Dormitory Based on Student' s Preference and Adaptation," EMARA Indones. J. Archit., vol. 4, no. 2, 2018. 
[9] N. Utaberta, "Rekonstruksi Pemikiran, Filosofi Dan Perancangan Arsitektur Islam Berbasiskan Al-Qur'an Dan Sunnah."

[10] N. Utaberta, Arsitektur Islam: pemikiran, diskusi, dan pencarian bentuk. Gadjah Mada University Press, 2008.

[11] N. Junara and T. Kusumadewi, "Studi Privasi dan Aksesibiltas dalam Rumah Hunian yang Memiliki Pondokan Mahasiswa ditinjau dari Nilai-nilai as Sunnah," El-HARAKAH (TERAKREDITASI), vol. 15, no. 1, p. 48, 2015, doi: 10.1886o/el.v15i1.2672.

[12] J. De Chiara and J. H. Callender, Time-saver Standards for Building Types. McGraw-Hill, 1990.

[13] E. Neufert and P. Neufert, Architects' Data. Wiley, 2000.

[14] H. Kılıçaslan, "Design of Living Spaces in Dormitories," Procedia - Soc. Behav. Sci., vol. 92, no. Lumen, pp. 445-451, 2013, doi: 10.1016/ j.sbspro.2013.08.699.

[15] M. Kriebel, "Student response to dormitory buildings," Hous. Soc., vol. 7, no. 1, pp. 54-66, 1980.

[16] A. A. Rahim and W. M. A. W. Seman, "Concept of privacy from islamic perspective in flood evacuation centre," Plan. Malaysia, vol. 17, no. 2, pp. 259-266, 2019, doi: 10.21837/ pmjournal.v17.i10.646.

[17] A. A. Rahim, N. Amirah, and A. Samad, "UNIVERSAL DESIGN FROM ISLAMIC PERSPECTIVER: MALAYSIAN MASJID," J. Arch. Plan. Constr. Manag. Vol. 4 Issue 2, vol. 4, 2018.

[18] R. Yaman, Z. Alias, and N. M. Ishak, "Beauty Treatment and Spa Design from Islamic Perspective," Procedia - Soc. Behav. Sci., vol. 50, pp. 492-501, 2012, doi: https:// doi.org/10.1016/j.sbspro.2012.08.053.

[19] M. A. Eben Saleh, "Privacy and communal socialization: The role of space in the security of traditional and contemporary neighborhoods in Saudi Arabia," Habitat Int., vol. 21, no. 2, pp. 167-184, 1997, doi: https:// doi.org/10.1016/S0197-3975(96)00055-0.
[20] E. Haji, K. Khan, S. Abbas, A. Yazdanfar, and A. Ekhlasi, "IMPORTANT ELEMENTS OF PRIVATE," vol. 15, no. 2, pp. 75-86, 2018.

[21] A. S. Bahammam, Architectural Patterns of Privacy in Saudi Arabian Housing [microform]. Thesis (M.Arch.)--McGill University, 1987.

[22] M. N. Asadullah and Maliki, "Madrasah for girls and private school for boys? The determinants of school type choice in rural and urban Indonesia," Int. J. Educ. Dev., vol. 62, no. March, pp. 96-111, 2018, doi: 10.1016/ j.ijedudev.2018.02.006.

[23] E. R. Babbie, The practice of social research. Nelson Education, 2015.

[24] B. L. Berg and H. Lune, Qualitative Methods for the Social Sciences. 2011.

[25] M. R. Roller and P. J. Lavrakas, Applied Qualitative Research Design: A Total Quality Framework Approach. Guilford Publications, 2015.

[26] E. van Wijk and T. Harrison, "Managing ethical problems in qualitative research involving vulnerable populations, using a pilot study," Int. J. Qual. Methods, vol. 12, no. 1, pp. 570-586, 2013, doi: 10.1177/160940691301200130.

[27] U. Flick, An Introduction to Qualitative Research. SAGE Publications, 2018.

[28] E. Hashimov, "Qualitative Data Analysis: A Methods Sourcebook and The Coding Manual for Qualitative Researchers: Matthew B. Miles, A. Michael Huberman, and Johnny Saldaña. Thousand Oaks, CA: SAGE, 2014. 381 pp. Johnny Saldaña. Thousand Oaks, CA: SAGE, 2013. 303 pp." Taylor \& Francis, 2015.

[29] N. Ünsalan, "a Study on the Relationships Among Space, and Time Concepts, and Attitudes of Students Within a Dormitory Environment," 2001, [Online]. Available: https:// pdfs.semanticscholar.org/f3d6/ coobd193c3b8989bed2469745e8601ea8ob2.pdf ?.ga=2.118905609.1896721791.1554712672998620124.1554712672.

[30] I. Khajehzadeh and B. Vale, "Lopez ( 1961 )). Most researchers focus on the influence of aspects of the facilities on student satisfaction ( Foubert et al ( 1998 ), La Roche et al ( 2010 ), Najib et al ( 2011 ), Amole ( 2008 and 2009 ), Hassanain ( 2008 ), Kaya and Erkip ( 2001 ), Th," pp. 163-174, 2014. 
[31] R. Wulandari, "Analisa Kaitan Desain Asrama Dengan Perilaku Penghuni Melalui Studi Analisa Konten Penelitian Sejenis," Idealog Ide dan Dialog Desain Indones., vol. 1, no. 3, pp. 219-231, 2016.
[32] M. A. Yusuf, A. Hayati, and M. Faqih, "CONCEPT OF FEMALE DORMITORY BEDROOMS BASED ON STUDENTS'PREFERENCE AND ADAPTATION," J. Archit., vol. 17, no. 2, pp. 169194, 2018. 